J. Asiat. Soc. Bangladesh, Sci. 40(2): 283-294, December 2014

\title{
SUBSTRATE SPECIFIC ZOOPERIPHYTON AND THEIR RELATIONSHIPS WITH WATER QUALITY PARAMETERS IN DHANMONDI LAKE, DHAKA, BANGLADESH
}

\author{
MD. EILIOUS HOSAIN'AND M. NIAMUL NASER \\ Advanced Fisheries Research Laboratory (AFRL), Department of Zoology, \\ University of Dhaka, Dhaka 1000, Bangladesh
}

\begin{abstract}
In the present investigation, zooperiphyton communities comprised protozoa, rotifera, copepoda, cladocera, ostracoda, conchostraca, insect's larvae, oligochaeta, nematoda and mollusca. The group of zooperiphyton on three substrates showed no significant differences $(P>0.05)$. Rotifers and protozoans were the most dominant group of total zooperiphyton abundance among three substrates. The interrelationships between zooperiphyton groups and physicochemical features of water as well as among different groups of zooperiphyton revealed that abundance and growth of zooperiphyton on substrates are influenced by water quality parameters and each with others. The ranges of physicochemical features of water of Dhanmondi lake were suitable for zooperiphyton communities including aquatic biota and also play a significant role to settle zooperiphyton on three substrates. That can help in enhancing productivity of the lake as well as sustaining aesthetic value of aquatic system.
\end{abstract}

Key words: Zooperiphyton, Interrelationships, Water quality parameters, Dhanmondi lake

\section{Introduction}

Young (1945) described periphytonas an assemblage of organisms growing upon the free surfaces of submerged objects of water and covering them with a slimy coating. Organisms (both plants and animals) attached or clinging to stems and leaves of rooted plants or other surfaces projecting above the bottom are called periphyton (Odum 1971). Periphyton refer to a complex community of microbiota (algae, bacteria, fungi, animals, and inorganic and organic detritus) which are attached to substrata of inorganic or organic, living or dead objects (Wetzel 1983). Periphyton are an essential component of the aquatic food chain. They are the primary producers in freshwater bodies including lakes where different forms are present in various locations viz: epilithic (rock) epipsamic (mud), epiphytic (plant), epipelic (sediments) and epizoic (animals) forms (Kadiri 2002). Some periphyton are sensitive indicators of water quality assessment and produce the early warning signal of water pollution (Browder et al. 1998). Periphyton can both directly and indirectly serve as a major regulator of the nutrient dynamics in lakes (Wetzel 2001). Dhanmondi lake, a semi artificial water body has been considered as an important component of Dhaka Metropolis for both recreational and fish culture point of view. At present, part of the lake used for sport fishing and the Department of Fisheries

\footnotetext{
'Corresponding author: Email: mehosin83@gmail.com
} 
Government of People's Republic of Bangladesh is operating aquaculture in the lake. Since its creation nearly half a century ago, the lake suffered tremendous threat of eutrophication until it was re-excavated a decade ago. During the pre-excavation period, a number of limnological researches have been carried out on the lake (Islam et al. 1979, Islam and Chowdhury 1979, Khondker et al.1988, Khondker and Rahim 1991, 1993; Khondker and Parveen 1992, Hasan et al. 1994). Khondker and Rahim (1993) also commented on the lake water quality by using periphytic and planktonic algae. Since there is no information available on zooperiphyton of the lake the present research on substrate specific zooperiphyton and their interrelationships with some water quality parameters was carried out.

\section{Materials and Methods}

Detail of the morphometric features and geographical location of the lake has been furnished in Islam and Chowdhury (1979). The sampling for the present research was carried out monthly from December 2010 to August 2011 between 10:00 and 11:00 am. Insitu measurement of free $\mathrm{CO}_{2}$, alkalinity, hardness, ammonia-nitrogen, nitrite-nitrogen were carried out by using $\mathrm{HACH}$ water quality testing kit (Model FF-2, USA); Air and water temperature, conductivity and TDS were measured by a HACH conductivity meter (Model HACH Sension5, USA). Lutron DO meter (Model DO 5509, Singapore) and HANNA pH meter (Model HI 8424, Italy) were used for determination of dissolved oxygen and $\mathrm{pH}$ of water respectively. Three locally available substrates namely Swietenia macrophylla $\left(910 \mathrm{~cm}^{2}\right)$ and Samanea saman $\left(980 \mathrm{~cm}^{2}\right)$ and Bambusa vulgaris $\left(840 \mathrm{~cm}^{2}\right)$ were installed vertically at one meter depth in replicates with equal distance at the lake bottom. After one month later, zooperiphyton colonized on the substrates were scraped and washed by tap water. After washing the zooperiphyton samples were taken into plastic bucket then sieved through a series of standard sieves having mesh size in a 2.0, 0.92 and $0.2 \mathrm{~mm}$ for the collection of larger samples like Molluscan shell. The remained sieved water was filtered through $55 \mu \mathrm{m}$ meshed plankton net and finally concentrated to $25-100 \mathrm{ml}$. The filtrates were immediately preserved by $4 \%$ buffer formaldehyde solution. Zooperiphyton taxa were identified by using keys from Ward and Whipple (1959), Needham and Needham (1962), Wetzel (1983), Ali and Chakrabarty (1992), Smith (2001) and Siddiqui et al. (2007). The enumeration was done by using a compound microscope (NOVA 950 ES, China) with the help of Sedgewick-Rafter cell (SR-Cell, USA) and expressed as number per meter square (individual $\mathrm{m}^{-2}$ ). Statistical analysis was done using Microsoft Office Excel 2007 and SPSS, a computer based program for Windows (Version 11.5, 2007. Systat, Inc. USA).

\section{Results and Discussion}

Water quality parameters: The air and water temperature varied from $18^{\circ}$ to $31^{\circ} \mathrm{C}$ and $19^{\circ}$ to $32^{\circ} \mathrm{C}$ respectively (Table 1 ). The almost all consistent results were reported by Hasan et al. (1994) from Dhanmondi Lake. In the present study, $\mathrm{pH}$ was found neutral to 
Table 1. Monthly fluctuation of different physico-chemical parameters with their ranges and mean values ( \pm SE) of Dhanmondi lake.

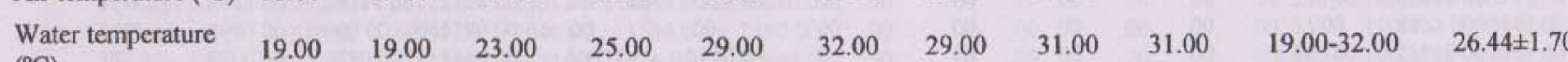

$\left({ }^{\circ} \mathrm{C}\right)$

$\mathrm{pH}$

$\mathrm{DO}(\mathrm{mg} / \mathrm{l})$

$\begin{array}{lllll}7.50 & 7.00 & 8.00 & 8.00 \quad 8.00\end{array}$

Free $\mathrm{CO}_{2}(\mathrm{mg} / \mathrm{l})$

$\begin{array}{lllll}7.50 & 8.50 & 5.00 & 8.60 & 8.50\end{array}$

8.00

$\begin{array}{lllll}35.00 & 25.60 & 28.50 & 35.60 & 21.50\end{array}$

(mg/I)

$\begin{array}{lllllllll}72.00 & 102.00 & 112.00 & 99.00 & 80.00 & 110.00 & 115.00 & 78.00 & 80.00\end{array}$

$7.00-8.70$

$7.88 \pm .17$

Hardness ( $\mathrm{mg} /$ )

$\begin{array}{lllll}80.00 & 96.00 & 99.00 & 101.00 & 99.00\end{array}$

$103.00 \quad 84.00$

87.00

Ammonia-nitrogen

(mg/l)

Nitrite-nitroge

(mg/l)

$\begin{array}{lll}0.05 & 0.04 & 0.06\end{array}$

$1.10 \quad .80$

$00 \quad 103.00$

$\begin{array}{r}87.00 \quad 96.00 \\ \hline\end{array}$

$14.20-36.40 \quad 25.64 \pm 2.90$

TDS (mg/l)

$202.80 \quad 201$

Conductivity $(\mu \mathrm{S} / \mathrm{cm}) 452.00$

$\begin{array}{rr}201.90 & 198.70 \\ 462.00 & 402.00\end{array}$

$0.19 \quad 0.04$

$1.20 \quad 0.90$

$72.00-115.00$

$94.22 \pm 5.57$

$80.00-103.00 \quad 93.88 \pm 2.72$

$0.60-2.40 \quad 1.05 \pm 0.18$

0.02-0.19 $\quad 0.05 \pm 0.01$

$\begin{array}{llll}0.02 & 0.02 & 0.02 & 0.02\end{array}$

$185.40-220.70 \quad 201.65 \pm 4.05$

$\begin{array}{lllllllll}402.00 & 455.00 & 462.00 & 376.00 & 386.00 & 376.00 & 386.00 & 376.00-462.00 & 417.44 \pm 13.03\end{array}$ 
Table 2. Monthly abundance (individual $/ \mathrm{m}^{2}$ ), range (individual $/ \mathrm{m}^{2}$ ) and mean values ( $\pm \mathrm{SE}$ ) of different groups of zooperiphytonon on bamboo, mehogoni and rain tree substrates in Dhanmondi Lake.

\begin{tabular}{|c|c|c|c|c|c|c|c|c|c|c|c|c|c|}
\hline Substrates & s Months & Protozoa & Rotifera & Copepoda & Cladocera & Ostracoda & Conchostrac & Insecta & Oligochaeta & Nematoda & Mollusca & G.Total & Percentage \\
\hline \multirow{13}{*}{ Bamboo } & Dec'10 & 2856.00 & 1190.00 & 714.00 & 476.00 & 714.00 & .00 & .00 & .00 & .00 & 60.00 & 6010.00 & \multirow{14}{*}{$39 \%$} \\
\hline & Jan' 11 & 9639.00 & 9639.00 & 1428.00 & 2856.00 & 1785.00 & .00 & .00 & .00 & .00 & 108.00 & 25455.00 & \\
\hline & Febr'11 & 12510.00 & 15433.00 & 3336.00 & 1668.00 & 3753.00 & .00 & .00 & .00 & .00 & 144.00 & 36844.00 & \\
\hline & Mar'11 & 25980.00 & 31397.00 & 5236.00 & 2856.00 & 5712.00 & .00 & 952.00 & 476.00 & .00 & 504.00 & 73113.00 & \\
\hline & Apr'11 & 41652.00 & 44744.00 & 6664.00 & 4760.00 & 6188.00 & 476.00 & 1428.00 & 952.00 & .00 & 1128.00 & 107992.00 & \\
\hline & May' 11 & 15409.00 & 32106.00 & 3753.00 & 1251.00 & 4757.00 & .00 & 1251.00 & .00 & .00 & 1032.00 & 59559.00 & \\
\hline & Jun'11 & 17493.00 & 24633.00 & 5355.00 & 4284.00 & 11442.00 & 1428.00 & 714.00 & .00 & .00 & 1032.00 & 66381.00 & \\
\hline & Jul'11 & 8211.00 & 21420.00 & 1785.00 & 1428.00 & 4641.00 & 1071.00 & 1071.00 & .00 & .00 & 1164.00 & 40791.00 & \\
\hline & Aug'11 & 9934.00 & 20562.00 & 2682.00 & 298.00 & 5364.00 & 894.00 & 894.00 & .00 & .00 & 1236.00 & 41864.00 & \\
\hline & Range & 2856.00 & $1190.00-$ & $714.00-$ & $298.00-$ & $714.00-$ & $.00-$ & $.00-$ & $.00-$ & .00 & $60.00-$ & $6010.00-$ & \\
\hline & Me: & 41652.00 & 44744.00 & 6664.00 & 4760.00 & 11442.00 & 1428.00 & 1428.00 & 952.00 & & 1236.00 & 107992.00 & \\
\hline & $\begin{array}{l}\text { Mean } \\
( \pm S E)\end{array}$ & 15964.88 & 22347.11 & $\begin{array}{l}3439.22 \\
(+668.62\end{array}$ & $\begin{array}{l}2208.55 \\
(+52870)\end{array}$ & 4928.44 & 429.88 & 701.11 & 158.66 & 0 & 712.00 & 50889.88 & \\
\hline & $\begin{array}{l}( \pm \text { SE) } \\
\text { Percentage }\end{array}$ & $\begin{array}{l}( \pm 3878.47 \\
c 32 \%\end{array}$ & $\begin{array}{l}( \pm 4322.02) \\
44 \%\end{array}$ & $\begin{array}{l}( \pm 668.62) \\
7 \%\end{array}$ & $\begin{array}{l}( \pm 528.70) \\
4 \%\end{array}$ & $\begin{array}{l}( \pm 1013.47) \\
10 \%\end{array}$ & $( \pm 188.14)$ & $( \pm 187.91)$ & $( \pm 112.19)$ & & $( \pm 167.18)$ & $\begin{array}{l}( \pm 9938.36) \\
100 \%\end{array}$ & \\
\hline \multirow{14}{*}{ Mehogoni } & Dec 10 & 2200.00 & 440.00 & 660.00 & .0 & $\frac{10 \%}{.00}$ & $\frac{1 \%}{.00}$ & $\frac{1 \%}{.00}$ & $\frac{0 \%}{00}$ & $\frac{0 \%}{.00}$ & $\frac{1 \%}{99.00}$ & 3399.00 & \\
\hline & Jan'11 & 6600.00 & 5280.00 & 1990.00 & 990.00 & 2640.00 & .00 & .0 & .00 & .00 & 110.00 & 17610.00 & \multirow{13}{*}{$34 \%$} \\
\hline & Febr'11 & 2640.00 & 660.00 & 1100.00 & .00 & .00 & .00 & .00 & .00 & .00 & 77,00 & 4477.00 & \\
\hline & Mar'11 & 8448.00 & 24784.00 & 3168.00 & 2464.00 & 6336.00 & .00 & .00 & .00 & .00 & 220.00 & 45420.00 & \\
\hline & Apr' 11 & 18920.00 & 26880.00 & 3960.00 & 3960.00 & .00 & .00 & 880.00 & 880.00 & 880.00 & 902.00 & 57262.00 & \\
\hline & May'11 & 10431.00 & 21960.00 & 3294.00 & 3843.00 & 52155.00 & 1647.00 & 5490.00 & .00 & 2196.00 & 913.00 & 101929.00 & \\
\hline & Jun'11 & 3960.00 & 9240.00 & 6600.00 & 2640.00 & 3960.00 & .00 & .00 & 2640.00 & .00 & 968.00 & 30008.00 & \\
\hline & Jul' 11 & 46200.00 & 29040.00 & 1760.00 & 2200.00 & 2640.00 & .00 & .00 & .00 & .00 & 1111.00 & 82951.00 & \\
\hline & Aug'11 & 24640.00 & 13475.00 & 2695.00 & 1155.00 & 2695.00 & .00 & .00 & .00 & .00 & 1155.00 & 45815.00 & \\
\hline & Range & 2200.00 & $440.00-$ & $660.00=$ & $.00-$ & .00 & $.00-$ & $.00-$ & .00 & $.00-$ & $77.00-$ & $3399.00-$ & \\
\hline & Kange & 46200.00 & 29040.00 & 6600.00 & 3960.00 & 52155.00 & 1647.00 & 5490.00 & & & 1155.00 & 101929.00 & \\
\hline & Mean & 13782.11 & 14639.88 & 2803.00 & 1916.88 & 7825.11 & 183.00 & 707.77 & 391.11 & 341.77 & 617.22 & 43207.88 & \\
\hline & $( \pm \mathrm{SE})$ & $( \pm 4774.41)$ & $( \pm 3780.18)$ & $( \pm 593.75)$ & & & & & $( \pm 297.37)$ & $( \pm 251.26)$ & $( \pm 158.11)$ & $( \pm 11273.8$ & \\
\hline & Percentage & $\mathrm{c} 32 \%$ & $34 \%$ & $7 \%$ & $4 \%$ & $18 \%$ & $0 \%$ & $2 \%$ & $1 \%$ & $1 \%$ & $1 \%$ & $100 \%$ & \\
\hline
\end{tabular}




\section{Contd.}

\begin{tabular}{|c|c|c|c|c|c|c|c|c|c|c|c|c|c|}
\hline Substrates & Months & Protozoa & Rotifera & Copepoda & Cladocera & Ostracoda & $\begin{array}{l}\text { Conchostrac } \\
\text { a }\end{array}$ & Insecta & Oligochaeta & Nematoda & Mollusca & G.Total & $\begin{array}{l}\text { Perce } \\
\text { ntage }\end{array}$ \\
\hline \multirow{12}{*}{ Rain tree } & $\operatorname{Dec}^{\prime} 10$ & 1836.00 & 408.00 & 1020.00 & 816.00 & .00 & .00 & .00 & 00 & .00 & 80.00 & 4160.00 & \multirow{12}{*}{$27 \%$} \\
\hline & $\operatorname{Jan}^{-11}$ & 816.00 & 408.00 & 612.00 & 204.00 & .00 & .00 & .00 & .00 & .00 & 90.00 & 2130.00 & \\
\hline & Febr'11 & 3825.00 & 2295.00 & 1275.00 & 1020.00 & .00 & .00 & .00 & .00 & .00 & 100.00 & 8515.00 & \\
\hline & Mar'11 & 14688.00 & 26010.00 & 3060.00 & 1530.00 & 5202.00 & .00 & .00 & .00 & .00 & 1010.00 & 51500.00 & \\
\hline & Apr'11 & 17952.00 & 45172.00 & 5304.00 & 4896.00 & 12240.00 & .00 & .00 & .00 & .00 & 1030.00 & 86594.00 & \\
\hline & May'11 & 31620.00 & 24990.00 & 2040.00 & 1530.00 & 8160.00 & .00 & .00 & .00 & .00 & 1100.00 & 69440.00 & \\
\hline & Jun' 11 & 3672.00 & 13872.00 & 1632.00 & 816.00 & 12648.00 & .00 & .00 & .00 & 408.00 & 1000.00 & 34048.00 & \\
\hline & JuI 11 & 7854.00 & 6069.00 & 2499.00 & 714.00 & 5355.00 & 714.00 & .00 & .00 & 714.00 & 800.00 & 24719.00 & \\
\hline & Aug'11 & 8160.00 & 11424.00 & 1632.00 & 1632.00 & 8160.00 & 1632.00 & .00 & .00 & .00 & 1010.00 & 33650.00 & \\
\hline & Range & $\begin{array}{l}816.00- \\
31620.00\end{array}$ & $\begin{array}{l}408.00- \\
45172.00\end{array}$ & $\begin{array}{l}612.00- \\
5304.00\end{array}$ & $\begin{array}{l}204.00- \\
4896.00\end{array}$ & $\begin{array}{l}00- \\
12648.00\end{array}$ & $\begin{array}{l}.00- \\
1632.00\end{array}$ & $\begin{array}{l}.00 \\
.00\end{array}$ & $\begin{array}{l}.00 \\
.00\end{array}$ & $\begin{array}{l}.00- \\
714.00\end{array}$ & $\begin{array}{l}80.00- \\
1100.00\end{array}$ & $\begin{array}{l}2130.00- \\
86594.00\end{array}$ & \\
\hline & $\begin{array}{l}\text { Mean } \\
( \pm \text { SE })\end{array}$ & $\begin{array}{l}10047.00 \\
( \pm 3311.96)\end{array}$ & $\begin{array}{l}14516.44 \\
( \pm 5014.36)\end{array}$ & $\begin{array}{l}2119.33 \\
( \pm 469.12)\end{array}$ & $\begin{array}{l}1462.00 \\
( \pm 456.47)\end{array}$ & $\begin{array}{l}5751.66 \\
( \pm 1670.67)\end{array}$ & $\begin{array}{l}260.66 \\
( \pm 188.62)\end{array}$ & $\begin{array}{l}.00 \\
.00\end{array}$ & $\begin{array}{l}.00 \\
.00\end{array}$ & $\begin{array}{l}124.66 \\
( \pm 86.31)\end{array}$ & $\begin{array}{l}691.11 \\
( \pm 152.61\end{array}$ & $\begin{array}{l}34972.88 \\
(19833.13)\end{array}$ & \\
\hline & Percentage & $29 \%$ & $42 \%$ & $6 \%$ & $4 \%$ & $16 \%$ & $1 \%$ & $0 \%$ & $0 \%$ & $0 \%$ & $2 \%$ & $100 \%$ & \\
\hline \multirow[b]{2}{*}{ Total } & Range & $\begin{array}{l}816.00- \\
46200.00\end{array}$ & $\begin{array}{l}408.00- \\
45172.00\end{array}$ & $\begin{array}{l}612.00= \\
6664.00\end{array}$ & $\begin{array}{l}.00- \\
4896.00\end{array}$ & $\begin{array}{l}.00- \\
52155.00\end{array}$ & $\begin{array}{l}.00- \\
1647.00\end{array}$ & \multirow{2}{*}{$\begin{array}{l}00- \\
5490.00 \\
469.62 \\
( \pm 213.25\end{array}$} & $\begin{array}{l}.00- \\
2640.00\end{array}$ & $\begin{array}{l}.00- \\
2196.00\end{array}$ & $\begin{array}{l}60.00- \\
1236.00\end{array}$ & $\begin{array}{l}2130.00- \\
107992.00\end{array}$ & \multirow[b]{2}{*}{$100 \%$} \\
\hline & $\begin{array}{l}\text { Mean } \\
( \pm \mathrm{SE})\end{array}$ & $\begin{array}{l}13264.66 \\
( \pm 2288.11)\end{array}$ & $\begin{array}{l}17167.81 \\
( \pm 2544.86)\end{array}$ & $\begin{array}{l}2787.18 \\
( \pm 340.22)\end{array}$ & $\begin{array}{l}1862.48 \\
( \pm 280.54)\end{array}$ & $\begin{array}{l}6168.40 \\
( \pm 1910.04)\end{array}$ & $\begin{array}{l}291.18 \\
( \pm 105.46)\end{array}$ & & $\begin{array}{l}183.25 \\
( \pm 106.55)\end{array}$ & $\begin{array}{l}155.48 \\
( \pm 89.47)\end{array}$ & $\begin{array}{l}673.44 \\
( \pm 88.78)\end{array}$ & $\begin{array}{l}43023.55 \\
( \pm 5891.34)\end{array}$ & \\
\hline \multirow{3}{*}{ ANOVA } & df & 2,24 & 2,24 & 2,24 & 2,24 & 2,24 & 2,24 & 2,24 & 2,24 & 2,24 & 2,24 & & \\
\hline & F & 0.551 & 1.039 & 1.282 & 0.580 & 0.191 & 0.458 & 1.235 & 1.149 & 1.22 & 0.098 & & \\
\hline & S & 0.584 & 0.369 & 0.296 & 0.567 & 0.827 & 0.638 & 0.309 & 0.334 & 0.299 & 0.907 & & \\
\hline
\end{tabular}


slight alkaline and varied from 7.00 to 8.70 (Table 1). The concentration of dissolved oxygen ranged from 3.40 to $8.70 \mathrm{mg} / \mathrm{l}$ in the month of June 2011 and March 2011 (Table 1). Free $\mathrm{CO}_{2}$ fluctuated from $14.20 \mathrm{mg} / \mathrm{l}$ in July 2011 to $36.40 \mathrm{mg} /$ lin May 2011 (Table 1). Total alkalinity of water varied from 72 to $115 \mathrm{mg} / \mathrm{l}$ in December 2010 and June 2011 (Table 1). The total hardness varied from 80 to $103 \mathrm{mg} / \mathrm{l}$ in the month of December 2010 and May 2011 (Table 1). The Ammonia-nitrogen concentration ranged from 0.60 to $2.40 \mathrm{mg} / \mathrm{l}$ with the maximum in February 2011 and minimum in December 2010 and June 2011 (Table 1). Nitrite -nitrogen ranged from 0.02 to $0.19 \mathrm{mg} /$ and it was maximum in March 2011 and minimum in May- August 2011 (Table 1). Islam and Saha (1975) observed similar results from Ramna lake, Dhaka. The minimum total dissolved solids were $185.40 \mathrm{mg} / \mathrm{l}$ in June and maximum was $220.70 \mathrm{mg} / \mathrm{l}$ in April (Table 1). Conductivity varied from 376 to $462.83 \mu \mathrm{S} / \mathrm{cm}$ of which maximum value was observed in April 2011 and minimum in July 2011 (Table 1). When physicochemical quality of water (post-excavation period of the lake) are compared with those of Khondoker and Parveen (1993) i.e. pre-excavation of bottom material marked differences were observed and it was observed that conductivity, alkalinity, free $\mathrm{CO} 2$ content and nitrate dropped significantly. Water temperature fluctuated in the same manner both in the study of Khondoker and Parveen (1993) and the present one. However, a slight increase in the maximum $\mathrm{pH}$ has been observed in the present investigation.

Zooperiphyton: The zooperiphyton communities of the lake were comprised of protozoa, rotifera, copepoda, cladocera, ostracoda, conchostraca, insect's larvae, oligochaeta, nematoda and mollusca. Substrate wise zooperiphyton communities and their monthly abundance, range, mean values and ANOVA values among substrates of the lake have been presented in the Table 2. Using three substrates, the abundance of total zooperiphyton varied from 2130 individual/ $\mathrm{m}^{2}$ in rain tree in January 2011 to 107992 individual $\mathrm{m}^{2}$ in bamboo in April 2011 (Table 2). In case of bamboo, it ranged from 6010 individual $/ \mathrm{m}^{2}$ in December 2010 to 107992 individual $/ \mathrm{m}^{2}$ in April 2011. While, in mehogoni substrates, it varied from 3399 individual/ $\mathrm{m}^{2}$ in December 2010 to 101929 individual $/ \mathrm{m}^{2}$ in May 2011. Whereas, in rain tree it fluctuated from 2130 individual $/ \mathrm{m}^{2}$ in January 2011 to 86594 individual/ $\mathrm{m}^{2}$ in April 2011. The group of zooperiphyton on three substrates showed no significant differences ( $>0.05$ ) (Table 2). Rai et al. $(2008,2010)$ recorded as $459826 \pm 32266$ individual $/ \mathrm{m}^{2}$ and $592770 \pm 233709$ individual $/ \mathrm{m}^{2}$ from bamboo and $472123 \pm 71505$ individual $/ \mathrm{m}^{2}$ and $469218 \pm 31646$ individual $/ \mathrm{m}^{2}$ from rice straw substrates in fresh water fish ponds of Bangladesh. On the basis of percentage composition $39 \%$ zooperiphyton settled on bamboo, $34 \%$ on mehogoni and $27 \%$ on rain tree substrates (Table 2). Seasonally, the highest value of zooperiphyton was observed in summer and the lowest in winter (Fig. 1). Sarwar and Zutshi (1988) also found maximum values of periphyton in winter and spring. Alam et al. (1997) observed the highest primary peak of periphyton in the month of March-April followed by secondary and tertiary peaks of lesser magnitude in the months of June and October respectively. Periphytic protozoans were dominant group in Dhanmondi lake 
among three substrates namely bamboo, mehogoni and raintree; it formed $32 \%, 32 \%$ and $29 \%$ of the total zooperiphyton abundance respectively (Table 2 ). Wenhui (1997) reported

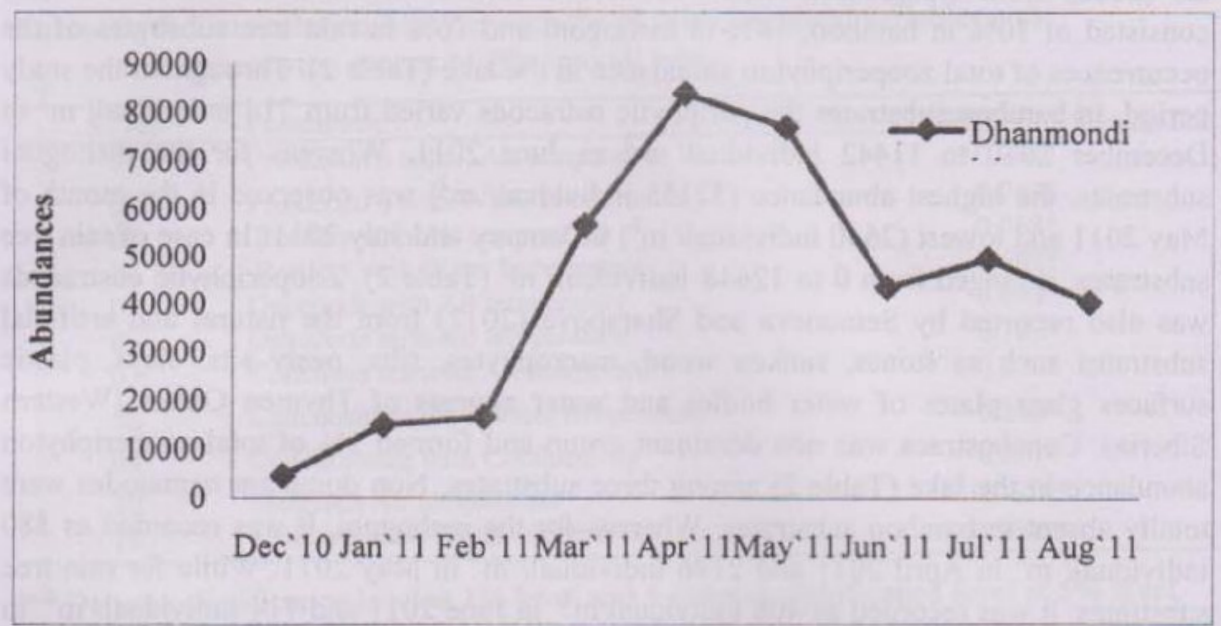

Fig. 1.Abundance of zooperiphyton population in Dhanmondi lake in different months.

that protozoans were dominant group as micro-zooperiphyton with percentages of $38.10 \%$ at Dianshan Lake in China. The abundance of protozoans zooperiphyton of bamboo substrates varied from 2856 to 41652 individual/ $\mathrm{m}^{2}$. While in the mehogoni substrates, it ranged from 2200 to 46200 individual $\mathrm{m}^{2}$. In case of rain tree substrates, it fluctuated from 816 to 31620 individual $/ \mathrm{m}^{2}$ (Table 2). Rotifers was the most dominant group among three substrates and it comprised of $44 \%$ in bamboo, $34 \%$ in mehogoni and $42 \%$ in raintree substrates in order to occurrence of total zooperiphyton abundance (Table 2). The total abundance of zooperiphyton among all three substrates of periphytic rotifers varied from 408 to 45172 individual $/ \mathrm{m}^{2}$. In case of bamboo pole, it fluctuated from 1190 individual $/ \mathrm{m}^{2}$ in December 2010 to 44744 individual $/ \mathrm{m}^{2}$ in April 2011. Whereas, on the mehogoni branch, rotifers settled on and ranged from 440 in December 2010 to 29040 in July 2011. While, in rain tree substrates, the highest abundance was 45172 individual $\mathrm{m}^{-2}$ in April 2011 and lowest 408 individual/ $\mathrm{m}^{2}$ in December 2010 (Table 2). More or less similar results had been observed by Wahab et al. (1999) from Bangladesh and Green (2003) from a tropical swamp, the Okavango Delta, Southern Africa. Copepods constituted $7 \%$ in bamboo and mehogoni and $6 \%$ in raintree in order to occurrences of total zooperiphyton abundance among three substrates of the lake (Table 2). The abundance of total periphytic copepods varied from 612 to 6664 individual/ $\mathrm{m}^{2}$. Periphytic cladocera constituted $4 \%$ of total zooperiphyton abundance among three substrates (Table 2). In the bamboo poles, it diverses from 298 individual $/ \mathrm{m}^{2}$ in August 2011 to 4760 individual $\mathrm{m}^{2}$ in April 2011. Whereas, in mehogoni substrates the maximum abundance ( 3960 individual $\mathrm{m}^{-2}$ ) was recorded in April 2011 and minimum 
(990 individual/ $\mathrm{m}^{2}$ ) in January 2011. In case of rain tree substrate, it fluctuated from 204 in January 2011 to 4896 in April 2011 (Table 2). Cladocera was also reported by Azim et al. (2002) from Bangladesh water. Ostracods settled on three substrates and also consisted of $10 \%$ in bamboo, $18 \%$ in mehogoni and $16 \%$ in rain tree substrates of the occurrences of total zooperiphyton abundance in the lake (Table 2). Throughout the study period, in bamboo substrates the periphytic ostracods varied from 714 individual/ $\mathrm{m}^{2}$ in December 2010 to 11442 individual $\mathrm{m}^{2}$ in June 2011. Whereas for the mehogoni substrates, the highest abundance ( 52155 individual $/ \mathrm{m}^{2}$ ) was observed in the month of May 2011 and lowest $\left(2640\right.$ individual/ $\left.\mathrm{m}^{2}\right)$ in January and July 2011. In case of rain tree substrates, it ranged from 0 to 12648 individual $/ \mathrm{m}^{2}$ (Table 2). Zooperiphytic costracods was also reported by Semoneva and Sharapova (2012) from the natural and artificial substrates such as stones, sunken wood, macrophytes, silts, peaty sits, clays, plastic surfaces glass plates of water bodies and water courses of Thymen Oblast (Western Siberia). Conchostraca was non dominant group and formed $1 \%$ of total zooperiphyton abundance in the lake (Table 2 ) among three substrates. Non dominant nematodes were totally absent in bamboo substrates. Whereas for the mehogoni, it was recorded as 880 individual/ $\mathrm{m}^{2}$ in April 2011 and 2196 individual/ $\mathrm{m}^{2}$ in May 2011. While for rain tree substrates, it was recorded as 408 individual $/ \mathrm{m}^{2}$ in June 2011 and 714 individual $/ \mathrm{m}^{2}$ in July 2011 (Table 2) during the study period. Nematodes was also reported by Hosain $e t$ al. (2011) from Curzon hall pond. Periphytic grazer molluscan fauna was non dominant group of zooperiphyton abundance of three substrates (Table 2) in the lake. The total abundance of periphytic grazer molluscan fauna fluctuated from 60 to 1236 individual/ $\mathrm{m}^{2}$. Macrozooperophytic molluscan fauna had also been reported by Skalskaya et al. (2008) from a small river and Sharapova (2010a and b). Periphytic insecta was one of the least dominant zooperiphyton among three substrates (Table 2). It was recorded from bamboo sticks and mehogoni branches and was totally absent from rain tree substrates (Table 2). Sharapova (2010b) observed that chironomid larva settled on immersed willow and stones from the UK river. Zooperiphytic oligochaeta was also non dominant group among three substrates in the lake (Table 2). Throughout the study period, oligochaeta was not found from rain tree branches but it was observed from bamboo and mehogoni substrates (Table 2 ). Sharapova (2010a) reported pollution signal producing periphytic oligocheats on rubble bedding at the base bridge and concrete pieces at Obrochnoye (oxbow lake) lake of the Tura River in Russia.

Interrelationships: The interrelationships between some water quality parameters and different zooperiphyton groups were determined and presented in Tables 3 and 4 . In Dhanmondi lake, protozoans showed significant positive correlation with the air temperature and the water temperature. Zooperiphytic rotifers exhibited positive correlation with air temperature and water temperature. Copepods had a positive correlation only with air temperature. Ostracods positively related with air temperature and water temperature of water. Conchostraca showed positive correlation with air temperature, water temperature and conductivity of water. The periphyton grazer 
molluscan fauna significantly correlated with air temperature and water temperature of water of Dhanmondi lake (Table 3).

Table 3. The interrelationships between the physico-chemical variables and zooperiphyton groups of Dhanmondi lake.

\begin{tabular}{clc}
\hline SI. No & Parameters & Correlation $(\mathrm{r})$ \\
\hline 01 & Protozoan's with Air temperature & $0.767^{*}$ \\
02 & Protozoan's with Water temperature & 0.7448 \\
03 & Rotifers with Air temperature & $0.758^{*}$ \\
04 & Rotifers with Water temperature & $0.669^{*}$ \\
05 & Copepods with Air temperature & $0.693^{*}$ \\
06 & Ostracods with Air temperature & $0.707^{*}$ \\
07 & Conchostraca with Air temperature & $0.770^{*}$ \\
08 & Conchostraca with Water temperature & $0.838^{*}$ \\
09 & Conchostraca with Conductivity & $0.801^{*}$ \\
10 & Mollusca Air temperature & $0.961^{* *}$ \\
11 & Mollusca with Water temperature & $0.960^{* *}$ \\
\hline
\end{tabular}

** Denotes significance level at $1 \%$ level and * denotes significance level at $5 \%$ level.

Among the zooperiphyton groups of Dhanmondi lake, rotifers showed significant positive correlation with protozoans, copepods, cladocera, and molluscans.Cladocera showed strong positive correlation with copepoda and oligichaeta. Molluscans exhibited strong positive relationships with conchostraca. Ostracods expressed positive correlation with insects and nematode. Insects had positive relationships with nematodes (Table 4).

Table 4. The interrelationships among zooperiphyton groups in Dhanmondi lake.

\begin{tabular}{clc}
\hline Sl. No & Parameters & Correlation $(\mathrm{r})$ \\
\hline 01 & Rotifers with Protozoans & $0.789^{*}$ \\
02 & Rotifers with Copepods & $0.838^{* *}$ \\
03 & Rotifers with Cladocera & $0.879^{* *}$ \\
04 & Rotifers with Mollusca & $0.706^{*}$ \\
05 & Cladocera with Copepods & $0.885^{* *}$ \\
06 & Cladocera with Oligocheats & $0.719^{*}$ \\
07 & Mollusca with Conchostraca & $0.829^{* *}$ \\
08 & Ostracoda with Insects & $0.938^{* *}$ \\
09 & Insecta with Nematodes & $0.957^{* *}$ \\
\hline
\end{tabular}

** Denotes significance level at $1 \%$ level and * denotes significance level at $5 \%$ level.

From the present investigation, it may be stated that the zooperiphyton composition, distribution and abundance were influenced by water quality parameters such as air and temperature and conductivity as well as each with others. Alam et al. (1997) reported a significant correlation coefficient between periphyton density and water temperature 
from a tropical pond receiving effluents from medical college complex (Aligarh, India) and domestic sewage. Rai and Sharma (1986) also calculated correlation coefficients among of the environmental factors with total cell counts and species diversity indices. Thus, zooperiphyton community may be helpful to use as sensitive indicator tool for determination of the ecological status as well as aesthetic value of lake aquatic system. The present investigation also indicates that zooperiphyton communities were well diversified and water quality properties of that lake were found to be suitable for aquatic biota including fish.

\section{Acknowledgements}

The first author is indebted to the Asiatic Society of Bangladesh for providing M. Phil scholarship. The research supported by the major multidisciplinary project entitled 'Epidemiology and Ecology of Vibrio choleraein Bangladesh' was financed by the National Institutes of Health (NIH) USA research Grant under the collaborative agreement between the International Center for Diarrhoeal Disease Research, Bangladesh (ICDDR,B) and Johns Hopkins Bloomberg School of Public Health. The authors gratefully acknowledge the SPGR grant for Dhaka Lake Pollution Project, Zoology, Dhaka University and Center for Advanced Studies and Research in Biological Sciences of Dhaka University for supporting this research.

\section{References}

Alam, M.A., A.A. Khan, A. Alam and R.K. Gaur.1997. Seasonal variation in periphyton density in a tropical pond receiving effluents from medical college complex. Journal of Ecotoxicology \& Envifonmental Monitoring.Vol. 7 (2): 135-138.

Ali, S. and T. Chakrabarty.1992. BangladesherMithaPanirAmerudandiPrani (A Book of Fresh water invertebrates of Bangladesh), $1^{\text {st }}$ ed. Bangla Academy, Dhaka, Bangladesh.

Azim, M.E., M.C.J. Verdegem, H. Khatoon, M.A. Wahab, A.A. Van Dam and M.C.M. Beveridge. 2002. A comparison of fertilization, feeding and three periphyton substrates for increasing fish production in freshwater pond aquaculture in Bangladesh. Aquaculture. 212: $227-243$.

Browder, J.A., P.J. Gleason and D.R. Swift.1998. Periphyton in the Everglades: spatial variation, environmental correlates and ecological implications In: Davis, S.M. and Ogden, J.C. (Eds). Everglades: The Ecosystem and its Restoration. Saint Lucie press, Delray Beach, Florida. pp. 379-418.

Green, J. 2003. Associations of planktonic and periphytic rotifers in a tropical swamp, the Okavango Delta, Southern Africa.Hydrobiologia. Vol. 490. (1-3):197-209.

Hasan, M., S. Ali and M.N. Naser.1994. Study on the natural productivity of Dhanmondi lake. Dhaka Univ. J. Biol. Sci. 3(1): 59-63.

Hosain, M.E., M.N. Naser, A.K.M.N. Kabir, S. Flora and M.M.R. Chowdury.2011. Substrate Preference of Zooperiphyton from an Urban Pond at Curzon Hall area, Dhaka, Bangladesh. J. Asiat. Soc. Bangladesh, Sci. 37(2): 295-312. 
Islam, A.K.M.N. and J.K. Saha. 1975. Limnological studies of the Ramna Lake at Dacca. Dacca Univ. Studies, 23(2): 39-46.

Islam, A.K.M.N., and A.R. Chowdhury.1979. Hydrobiological studies of Dhanmondilake, Dacca II. Phytoplankton. J. Asiatic Soc. Bangladesh (Sci.). 5(2): 47-57.

Islam, A.K.M.N., M. Rahman and A.R. Choudhury.1979. Hydrobiological studies of Dhanmondi lake, Dacca.I. Macrophytes and benthic flora. J. Asiatic Soc. Bangladesh(Sci.). 5(1): 59 75.

Kadiri, M.O. 2002. Periphyton of Ikpoba River. B. Sc Thesis, University of Benin, Benin City 84 pp.

Khondker, M., A. K. M. N. Islam and R. Islam.1988. Studies on the primary productivity of Dhanmondi lake. Dhaka Univ. Stud.Part E, 3: 15-21. (Bangladesh, January)

Khondker, M and S. Rahim.1991. Investigation on the water quality of Dhanmondi lake. I. Physicochemical features. Bangladesh J. Bot. 20: 183-191.

Khondker, M. and L. Parveen. 1992. Study on the physical and chemical limnology of a shallow, hypertrophic artificial lake. Bangladesh J. Sci. Res. 10: 9-16.

Khondker, M. and S. Rahim.1993. Investigation on the water quality of Dhanmondi lake II. Periphytic and planktonic algae as indicators. Bangladesh J. Bot. 22: 49-53.

Needham, J.G. and P.R. Needham. 1962. A Guide to the Study of Fresh-Water Biology. HoldenDay,Inc., San Francisco.

Odum, E.P. 1971. Fundamentals of Ecology. 3rd edition, N.B. Saunders Company, London, 375 pp.

Rai, D.N. and U.P. Sharma.1986. Studies on the occurrence of periphyticTestacea (Protozoa: Rhizopoda) in the weed infested swamps of Darbhanga (North Bihar). Indian Journal of Ecology. Vol. 13 (2): 334-339.

Rai, S, Y. Yi, M.A. Wahab, A.N. Bart and J.S. Diana. 2010. Comparison of the Growth and Production of Carps in Polyculture Ponds with Supplemental Feed using Rice Straw and Kanchi as Substrates. Our Nature. 8: 92-105

Rai, S., Y. Yi, M.A. Wahab, A.N. Bart and J.S. Diana. 2008. Comparison of rice straw and bamboo stick substrates in periphyton-based carp polyculture systems.Aquaculture Research. 39: 464-473

Sarwar, S.G. and D.P. Zutshi. 1988. Species distribution and community structure of periphytic algae on artificial substrate. Tropical Ecology. Vol. 29(2): 116-120.

Semoneva, L.M. and T.A.Sharapova.2012. Ostracods (crustacean and ostracoda) in the zooperiphyton of water bodies and water courses of Thymen Oblast (Western Siberia). Inland Water Biology.Vol.5 (1): 61-68.

Sharapova, T.A. 2010a. Abiotic and Biotic Factors Affecting Zooperiphyton Development in a wterflow of a Cooling Water Pool.Contemporary Problems of Ecology.Vol.3 (4): 495 497.

Sharapova, T.A. 2010b. Spatial Structure of Zooperiphyton in a small River (West Siberia). Inland Water Bology. Vol. 3 (2): 149- 154.

Siddiqui, K.U., M.A. Islam, SM.H. Kabir, M. Ahmed, A.T.B. Ahmed, A.k.A. Rahman and E.U. Haque.2007. Encyclopedia of Flora and Fauna of Bangladesh (Molluscs, Vol. 17). Asiatic Society of Bangladesh (5 Old Secretariat Road, Namtali, Dhaka 1000, Bangladesh).

Skalskaya, I. A., A. I. Bakanov and B. A.Flerov. 2008. Study on Zooperiphyton and Zoobenthos of a small River. Inland water Biol. Vol. 1: 84 - 92. 
Smith, D.G. 2001. Pennak's Freshwater Invertebrates of the United States ( $4^{\text {th }}$ Edition, Protozoa to Crustacea). John Wiley and Sons, Inc.

Wahab M.A., M.E. Azim, M.H. Ali, M.C.M. Beveridge and S. Khan.1999. The potential of periphyton-based culture of the native major carp calbaush, Labeo calbasu (Hamilton). Aquaculture Research. 30: 409-419.

Ward, H.B. and G.C. Whipple.1959. Freshwater Biology. John Wiley and Sons Inc. New York. $423 \mathrm{pp}$.

Wenhui, Y. 1997. Preliminary studies on zooperiphyton community in Dianshan lake. $J$ Acta Hydrobiologica Sinica, 21(2):114-122.

Wetzel, R.G. 1983. Attached algal-substrata interactions; fact or myth, and when and how? In Periphyton of freshwater ecosystems(Ed. R.G. Wetzel), Dr. W. Junk publishers, The Hague.

Wetzel, R.G. 2001.Limnology.Lake and River Ecosystems. Academic Press, San Diego.

Young, O.W. 1945. A Limnological Investigation of Periphyton in Douglas Lake, Michigan.Trans. Amer. Micr. Soc. Vol. 64(1): 1-20.

(Received revised manuscript on 20 October 2014) 